\title{
Using Hawgent Dynamic Mathematics Software in Teaching Trigonometry
}

\author{
https://doi.org/10.3991/ijet.v15i10.13099 \\ Tommy Tanu Wijaya ${ }^{\bowtie}$, Zhou Ying, Aditya Purnama \\ Guangxi Normal University, Guilin, China \\ tanuwijayategmail.com
}

\begin{abstract}
Learning media is a help assistant for students to understand mathematics concept. Sometimes textbooks are very boring and not interesting therefore an innovation using a technology based media is needed. This research aims to make a learning media to improve students' ability on the topic of trigonometry. The learning process will use Hawgent Dynamic Mathematics Software as a mathematics learning media. The problems that we are going to find out through this research are 1) can developing a learning media such as Hawgent Dynamic Mathematics Software improve students' mathematical ability? and 2) did the student show a positive response in the learning process when using hawgent dynamic mathematic software? This research will use the ADDIE method. The target of this research are 30 high school students. The instruments use for this research are the cognitive test, interview and observation. According to the research result, there is an improvement in the students' mathematical ability for trigonometry when using hawgent dynamic mathematic software. This means that the implementation of Hawgent Dynamic Mathematics Software in the learning process is successful. Students are more active and enthusiastic in class. In conclusion, developing Hawgent Dynamic Mathematics Software can improve the students' mathematical ability in trigonometry as students' show positive response when the learning process is helped by hawgent.
\end{abstract}

Keywords-Hawgent Dynamic Mathematics Software, Trigonometry

\section{Introduction}

Mathematics is one of the subject that has a lot of advantages in our everyday life $[1,2,3]$. Mathematics allows students to train their mental that will also effect their intellectual growth. Understanding the concept is very important when studying mathematics[4], like stated by Kulsum[5] that mathematics focuses on the concept. That is why the goal of learning mathematics is so that students' understand the concept of mathematics, able to explain the relationship of one concept to another and able to use the concept of algorithm in a flexible, accurate, efficient and correct way when solving a problem[6,7].

Mathematics is a difficult subject that resulted in students facing difficulties to understand mathematics as it is an abstract subject[8]. A lot of students have difficulties 
learning mathematics because they do not fully understand the concept from the mathematics problem and these affects the students' interest in learning as they easily get bored when studying [9]. According to the research done in Indonesia, it stated that trigonometry is one of the topic of mathematics that is considered hard to learn[10]. Trigonometry is a topic for high school students [10,11]. The students find related angles and trigonometry identity difficult where in a lot of students are still unable to prove the identity of trigonometry.

Hawgent Dynamic Mathematics Software is a mathematic learning media from Guangzhou, China. Hawgent is a dynamic math software with many features, such as flexible and convenient operation, powerful math teaching functions, and rich dynamic resource series. Hawgent can handle mathematical knowledge of geometry, algebra, triangle, probability, etc[12]. It can achieve core effects such as dynamic curve drawing and object trajectory, and vividly show the process of mathematical object generation. If used properly, it can penetrate the classroom or help conceptual teaching In this journal, we will explain the media that is used to learn Trigonometry by using hawgent dynamic mathematic software.

\section{$2 \quad$ Method}

This research uses the ADDIE method with the following stages (Analysis, Design, Development, Implementation and Evaluation) $[13,14]$. In the analysis stage, we need to see the need and the difficulties faced by students when learning trigonometry. In the design stage, researchers would design a learning media on the topic of geometry using Hawgent Dynamic Mathematics Software according to the teacher's requirement and the difficulties faced by the students when solving trigonometry problems. In the development state, after the researchers designed a good learning media, the media and material expert will validate the learning media. In the implementation stage, teachers will use Hawgent Dynamic Mathematics Software to teach trigonometry to senior high school students and see the students' response to hawgent as a learning media. Lastly, in the evaluation stage, researchers will make improvements to the learning media according to the suggestion and input from the teachers and student. This research only focus on the validity and practicality of the product.

This research uses a questionnaire that is given to the media expert, material expert, students and teachers. Researchers also interviewed the senior high school students in Cimahi to know the students' response on hawgent as a learning media. The validation criteria from media and material experts can be seen in table 1 .

Table 1. Validation criteria from media and material experts

\begin{tabular}{|c|l|l|}
\hline Percentage & \multicolumn{1}{|c|}{ Criteria } & \multicolumn{1}{c|}{ interpretation } \\
\hline $76-100$ & Valid & No revision needed \\
\hline $50-75$ & Valid enough & Fair enough/ small revision \\
\hline $26-50$ & Less valid & A lot of revision needed \\
\hline $0-25$ & Invalid & Total revision needed \\
\hline
\end{tabular}


The validation criteria table below is given by mathematics high school teachers on hawgent dynamic mathematic software.

Table 2. Validation criteria from the teachers

\begin{tabular}{|c|l|l|}
\hline Percentage & \multicolumn{1}{|c|}{ Criteria } & \multicolumn{1}{c|}{ interpretation } \\
\hline $76-100$ & Valid & No revision needed \\
\hline $50-75$ & Valid enough & Fair enough/ small revision A few revision needed \\
\hline $26-50$ & Less valid & A lot of revision needed \\
\hline $0-25$ & Invalid & Total revision needed \\
\hline
\end{tabular}

\section{Results and Discussion}

\subsection{Result}

The trigonometry learning media development using Hawgent Dynamic Mathematics Software got a score of $84 \%$ from the media expert. This means that the media is valid and feasible to be implemented to senior high school students. Table 3 shows the ratings given by the media experts for Hawgent Dynamic Mathematics Software based on the questionnaire given.

Table 3. Assessment result from Media Expert

\begin{tabular}{|c|l|c|c|c|}
\hline No & \multicolumn{1}{|c|}{ Indicators } & Number of item & Value & percentage \\
\hline 1 & Design and image display & 5 & 23 & $92 \%$ \\
\hline 2 & Trigonometry solving problem process is shown clearly & 5 & 22 & $88 \%$ \\
\hline 3 & Easiness of using the media & 5 & 18 & $72 \%$ \\
\hline 4 & How well students understand the Hawgent media & 5 & 21 & $84 \%$ \\
\hline & Average & & & $84 \%$ \\
\hline
\end{tabular}

There is also the assessment of Hawgent Dynamic Mathematics Software from the material expert that got a result of $97 \%$. This means that the learning media is valid and worthy to be tested on senior high school students as a learning media to study the trigonometry topic. The assessment result from the material expert can be seen in table 4.

Table 4. Assessment result from Material Expert

\begin{tabular}{|l|l|c|c|c|}
\hline No & \multicolumn{1}{|c|}{ Indicators } & Number of item & Value & percentage \\
\hline 1 & Explain the definition of trigonometry & 5 & 22 & $88 \%$ \\
\hline 2 & Explain the sine, cosine and tangent concept & 5 & 20 & $80 \%$ \\
\hline 3 & Steps to draw trigonometry graphs & 5 & 24 & $96 \%$ \\
\hline 4 & Solve trigonometry problems clearly & 5 & 21 & $84 \%$ \\
\hline & Average & & & $87 \%$ \\
\hline
\end{tabular}




\subsection{Discussion}

In the analysis stage, researches collected data on the difficulties faced by senior high school students on the 10th grade trigonometry based on the 2013 curriculum. Figure 1 shows the difficulties faced by students when solving trigonometry problems.

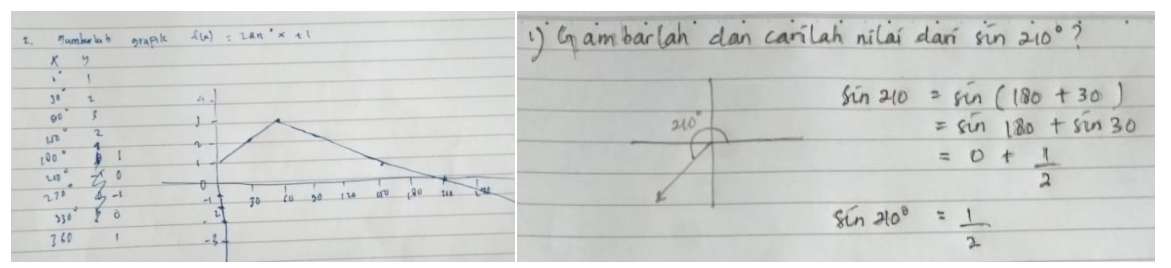

a) Straight line graph

b) Students' errors when tracing angles

Fig. 1.

In figure 1a, we can see that students drew the trigonometry graph that has an angle of $0<\mathrm{x}<360$ as a straight line. However, the correct graph for trigonometry function is curve graph. In figure $1 \mathrm{~b}$, the students only remember the trigonometry formula for special angles. As a result, the students did not pay attention to the quadrant and their answer were incorrect. The problems faced by students when doing trigonometry problems are shown in table 5 .

Table 5. Students' ability in solving the Pre-test problems

\begin{tabular}{|c|l|c|c|}
\hline No & \multicolumn{1}{|c|}{ Findings } & Number of Students & $\begin{array}{c}\text { Percentage } \\
(\%)\end{array}$ \\
\hline 1 & Understanding the definition of trigonometry & 10 & 33.33 \\
\hline 2 & Explaining how to draw trigonometry graph & 22 & 73.33 \\
\hline 3 & Connect graph and quadrant on trigonometry & 12 & 40.00 \\
\hline 4 & How to make problem solving process & 10 & 31.25 \\
\hline 5 & Evaluate the outcome of problem solving & 8 & 26.67 \\
\hline 6 & Describe trigonometry graph according to the problem & 13 & 43.33 \\
\hline
\end{tabular}

From table 5 we can see the problems faced by the students when solving trigonometry problems and it will be taken into consideration and requirement to make the learning media using Hawgent Dynamic Mathematics Software as a solution to the problems faced by the students. There are a few factors that need to be remembered when making the learning media such as a) hawgent should make the students more active to understand the concept of trigonometry, $b$ ) hawgent should be able to picture out clearly trigonometry graph, c) hawgent should be able to explain the relationship between graph and quadrant in trigonometry, d) hawgent should be able to show clearly and correctly the solution to the problem from the beginning until the end and e) hawgent should be able to give various easy solutions on how to solve the problem. 


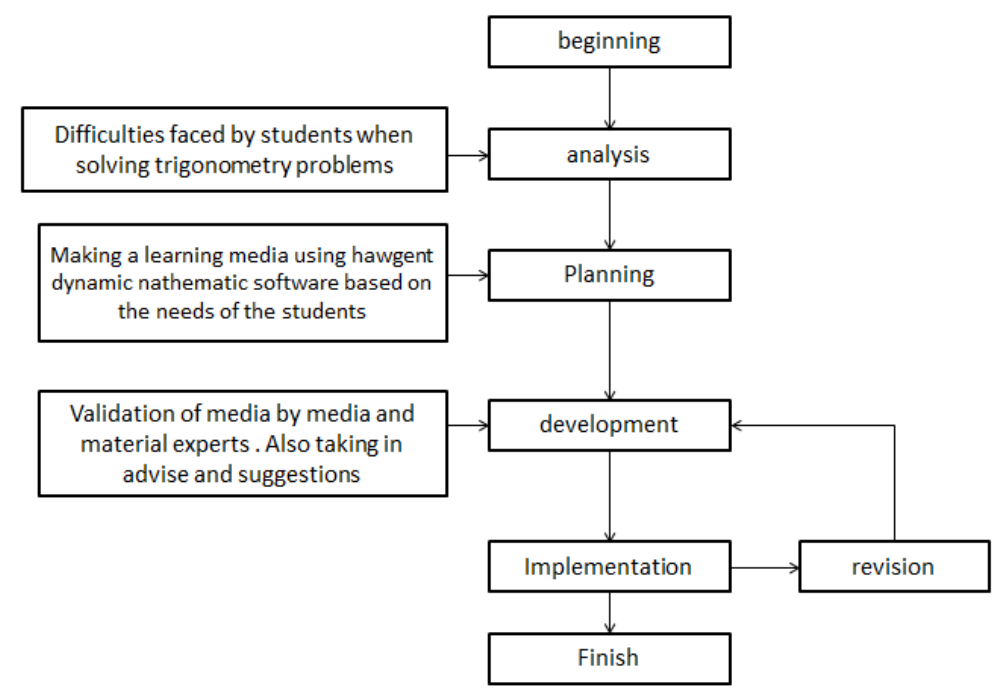

Fig. 2. Steps to make the learning media

The researchers planned to make a learning media on the topic of trigonometry by using Hawgent Dynamic Mathematics Software according to the problems faced by the students. The plan is designed using a flowchart so that we can see clearly that the learning strategies using hawgent can be achieved or students are able to understand the basic concept trigonometry.

In figure 2 we can see from the analysis stage that the researchers collected data on the students' problems which then becomes important information in making the learning media on the topic of trigonometry using hawgent dynamic mathematic software. In the planning stage, the researchers make the learning media using Hawgent Dynamic Mathematics Software according to the needs of the students and teachers which then are validated by the media and material experts. The researchers will keep on developing the learning media until they are ready to be implemented.

After making the learning media using hawgent dynamic mathematic software, we can see in table 6 the respond and input from the teachers, media and material experts.

Table 6. Responds from teachers, media and material experts.

\begin{tabular}{|l|l|}
\hline \multicolumn{1}{|c|}{ Response } & \multicolumn{1}{c|}{ description } \\
\hline Media expert & Add more pictures and supporting statement \\
\hline & The display must be made lighter \\
\hline Materialexpert & The media need to focus on the ways to solve trigonometry problems \\
\hline & An explanation of quadrant and graph need to be in one screen display \\
\hline Teachers & The language in that is use in the hawgent program need to be simplified \\
\hline
\end{tabular}


According to table 6 on the responses and inputs from the teachers, media and material experts, the learning media need to be simplified and more definite based on the understanding, basic concept of trigonometry and ways to draw trigonometry graphs.

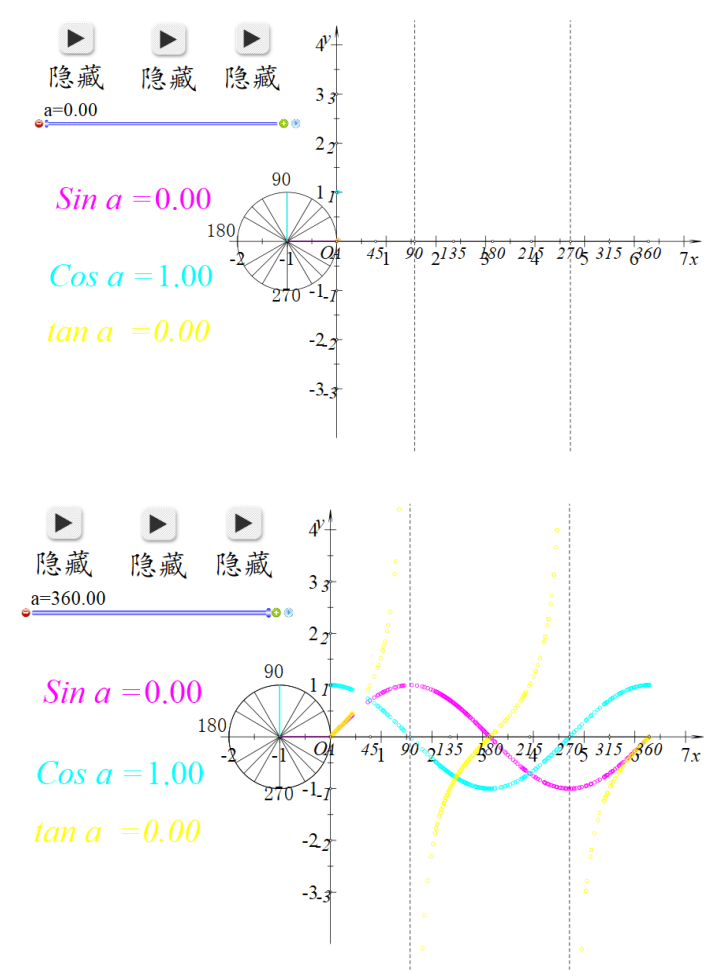

Fig. 3. Trigonometry graph explanation using Hawgent Dynamic Mathematics Software

Figure 3 explains how to draw the basic concept of trigonometry graph which is a curve line not a straight line. In addition, Hawgent Dynamic Mathematics Software is interesting, easy to understand and more interactive for the students. After implementing the media, students give their respond to Hawgent Dynamic Mathematics Software with the topic of trigonometry. 5 out of 30 student were interviewed to give out their opinion on the learning media and the result is shown in the table below.

Table 7. Responses from the students

\begin{tabular}{|c|l|}
\hline Student & \multicolumn{1}{|c|}{ Response } \\
\hline S-1 & I will not make a mistake again when drawing the trigonometry graph \\
\hline S-2 & I can nderstand better when using hawgent compared to the traditional teaching method \\
\hline S-3 & Hawgent makes me understand about quadrants in trigonometry \\
\hline S-4 & Now I can clearly understand the concept of trigonometry \\
\hline S-5 & The display of trigonometry graph is very interesting \\
\hline
\end{tabular}


The students tried using Hawgent Dynamic Mathematics Software on their own so that they will be able to clearly understand how the learning media works on the topic of trigonometry. This way, the students will be able to give their input and opinions on hawgent dynamic mathematic software. In the end of the class, the teachers interviewed 3 students to give out their input and opinion on Hawgent Dynamic Mathematics Software and their response are in the table below.

Table 8. Students' interview result

\begin{tabular}{|c|c|}
\hline Question & Responses \\
\hline \multirow{3}{*}{$\begin{array}{l}\text { Is hawgent helpful in solving trigonometry } \\
\text { problems? }\end{array}$} & Very helpful \\
\hline & It makes the problem easier to understand \\
\hline & $\begin{array}{l}\text { Very helpful. I hope that other mathematics topic can be } \\
\text { made using hawgent }\end{array}$ \\
\hline \multirow{3}{*}{$\begin{array}{l}\text { What do you think about hawgent dynamic } \\
\text { mathematic software? }\end{array}$} & Hawgent can help solve mathematics problems \\
\hline & Hawgent are made for students to learn \\
\hline & Hawgent is very flexible and very good \\
\hline What are the weakness of the media & The language is not universal \\
\hline
\end{tabular}

\section{Conclusion}

According to the research above, Hawgent Dynamic Mathematics Software on the topic of trigonometry can be implemented to 10th grade students. This can be seen from the rating result from the media material expert which are $84 \%$ and $87 \%$ respectively. We can also see that Hawgent Dynamic Mathematics Software got a positive response from the students from the start until the end of the learning process.

\section{$5 \quad$ References}

[1] Wijaya, T. T., \& Afrilianto, M. (2018). Kemampuan Komunikasi Matematis Siswa Smk. Jpmi (Jurnal Pembelajaran Matematika Inovatif), 1(1), 21-28. https://doi.org/10.22460/jp mi.v1i3.219-228

[2] Zuyyina, Hasna, Tommy Tanu Wijaya, and Eka Senjawati. (2018). "Kemampuan Koneksi Matematis Siswa Smp Pada Materi Lingkaran.” Sosiohumaniora 4(2): 79-90. https://doi. org/10.30738/sosio.v4i2.2546

[3] Sharzadin, Adilzada et al. 2019. "Teaching Internship in Math Teacher Education.” International Journal of Emerging Technologies in Learning 14(12): 57-70.

[4] Khotimah, K., Yuwono, I., Rahardjo, S., Universitas, P. M., \& Malang, N. (2016). Penerapan Pembelajaran Inkuiri untuk Meningkatkan Hasil Belajar Trigonometri pada Siswa Kelas X. Jurnal Pendidikan, 1(11), 2158-2162. https://doi.org/10.26740/jrpd.v2n2.p195-203

[5] Kulsum, Sri Islami et al. (2019). "Analysis On High School Students ' Mathematical." Jurnal Cendekia : Jurnal Pendidikan Matematika 03(02): 431-36. https://doi.org/10.31004/ cendekia.v3i2.128

[6] Nizarwati, N., Hartono, Y., \& Aisyah, N. (2013). Pengembangan Perangkat Pembelajaran Berorientasi Konstruktivisme Untuk Mengajarkan Konsep Perbandingan Trigonometri 
Siswa Kelas X Sma. Jurnal Pendidikan Matematika, 3(2). https://doi.org/10.22342/jpm.3.2. 328.

[7] Wijaya, T. T., Dewi, N. S. S., Fauziah, I. R., \& Afrilianto, M. (2018). Analisis Kemampuan Pemahaman Matematis Siswa Kelas IX Pada Materi Bangun Ruang. UNION: Jurnal Ilmiah Pendidikan Matematika, 6(1), 19-28. https://doi.org/10.30738/.v6i1.2076

[8] Qin, L., Zhou, Y., \& Tanu, W. T. (2019). The Analysis of Mathematics Adversity Quotient of Left Behind Junior High School Students in Rural Areas. 331-342. https://doi.org/10.42 36/jss.2019.710028

[9] Mushipe, Melody, and Ugorji I. Ogbonnaya. 2019. "Geogebra and Grade 9 Learners' Achievement in Linear Functions." International Journal of Emerging Technologies in Learning 14(8): 206-19. https://doi.org/10.3991/ijet.v14i08.9581

[10] Bernard, M., Sumarna, A., Rolina, R., \& Akbar, P. (2019). Development of high school student work sheets using VBA for microsoft word trigonometry materials. Journal of Physics: Conference Series, 1315(1). https://doi.org/10.1088/1742-6596/1315/1/012031

[11] Mulyawati, C., Salmawati, S., Subianto, M., \& Wafdan, R. (2017). Teaching Media Development of Mathematic in the Materials Trigonometry Sum and Two Angles Difference By Using Gui Matlab. Jurnal Natural, 17(2), 69. https://doi.org/10.24815/jn.v0i0.7032

[12] Cunhua, Liu, Zhou Ying, Ouyang Qunzhuang, and Tommy Tanu Wijaya. 2019. "Mathematics Course Design Based On Six Questions Cognitive Theory Using Hawgent Dynamic Mathematic." Journal On Education 02(01): 36-44.

[13] Kristanto A, Mariono A and Nuryati D W 2018 Developing Media Module Proposed to Editor in Editorial Division. J. Phys. Conf. Ser. 947 012054. https://doi.org/10.1088/1742$\underline{6596 / 947 / 1 / 012054}$

[14] Bernard, M., Sumarna, A., Rolina, R., \& Akbar, P. (2019). Development of high school student work sheets using VBA for microsoft word trigonometry materials. Journal of Physics: Conference Series, 1315(1). https://doi.org/10.1088/1742-6596/1315/1/012031

\section{Authors}

Tommy Tanu Wijaya is master degree student of mathematics and statistics at Guangxi Normal University, Yanshan no. 1, Guilin, China.

Zhou Ying is a Professor curriculum of mathematics education in Guangxi Normal University, China.

Aditya Purnama has graduated from Guangxi Normal University, Guilin, China. with masters degree in mathematics and statistics.

Article submitted 2020-01-09. Resubmitted 2020-02-23. Final acceptance 2020-02-23. Final version published as submitted by the authors. 